\title{
Reporting on the Issues of Research Rigour and Ethics: The Case of Publications Using Qualitative Methods in the Croatian Social Science Journals
}

\author{
Tanja VUČKOVIĆ JUROŠ \\ Social Work Study Centre, Faculty of Law, University of Zagreb, Croatia \\ tanja.vuckovic.juros@gmail.com
}

\begin{abstract}
This paper discusses the issues of research rigour and ethics in the qualitative research on the case of studies published in the Croatian social science journals. The author discusses the qualitative research applications of the concepts of generalizability, validity and reliability and the relevance of the ethical considerations in the qualitative research, and examines the conventions of reporting on these issues in the Croatian social science journals. For these purposes, the author examined articles using qualitative methods in which the researcher interacted with the research participants (in-depth interviews, focus groups interviews, observation) published in 2000-2009 in seven Croatian journals indexed in the International Bibliography of Social Sciences (IBSS) and/or Social Sciences Citation Index (SSCI). The results testify to the underdeveloped conventions of reporting on the ethical issues, which are further reinforced by the weak institutional accountability in the domain of ethics regulations. Furthermore, the misconception about the lack of research rigour in qualitative studies is often responsible for the accusations of these studies being "less scientific". But, just the opposite, good qualitative studies require stricter regimes of researcher accountability in terms of her/his research decisions and procedures. However, the reports on the research steps and the discussions of generalizability, validity and reliability, as adapted to the nature of the qualitative studies, are mostly missing from the Croatian publications using qualitative methods. This reinforces the misconceptions about the qualitative studies and disables the discerning reader from evaluating the credibility and legitimacy of the qualitative studies' results.
\end{abstract}

Key words: research rigour, ethics, qualitative research, generalizability, validity, reliability, social sciences 
... ethnography's epistemology, in its insistence on investigating the viewpoint of those studied, is indeed like that of other social scientists, just more rigorous and complete.

(Becker, 1996: 59)

The present paper will not discuss the epistemology of qualitative or ethnographic research.* Nevertheless, Becker's words are a good introduction to the topic of reporting on participant-based qualitative research. They emphasize one important and often overlooked aspect of qualitative research, which goes beyond claiming the scientific status of the qualitative research. This claim is that qualitative research methods require researchers to approach them in particularly rigorous and reflexive ways. The argument of the present paper builds upon this by claiming that much of the "unscientific" reputation of the qualitative research can be attributed to the often undeveloped conventions of reporting on qualitative research. As the present paper will demonstrate, these undeveloped conventions of reporting on research rigour and ethical issues in qualitative research are also one of the main problems plaguing qualitative articles published in Croatian social science journals. They, in turn, reinforce the misconceptions about the "unscientific" nature of the qualitative research and disable the discerning reader from evaluating the credibility and legitimacy of the qualitative studies' results.

The issues of ethics and research rigour are two key issues in any discussion on participant-based qualitative research where the researcher interacts with the "human subjects" (respondents, informants, research participants) in much more involved ways than the quantitative researchers usually do. In regard to ethics, the procedure of the entry into the field and gaining the respondents/informants' approval is crucial. However, in the Croatian social sciences, the institutional procedures, such as the ethics reviews by professional human subjects' boards, are underdeveloped. The weak institutional accountability is further reinforced by the underdeveloped conventions of reporting on ethical issues in published articles. Rather, this often remains a researcher's personal decision and not something that is required from her/him. Next, in regard to research rigour, the smaller distance between the qualitative researcher and what she/he studies means that the researcher needs to adhere to a stricter regime of accountability in terms of research

\footnotetext{
* Earlier versions of this paper were presented at the Qualitative Transitions conference in Rijeka in November 2010 and at a meeting of the Section for Qualitative Research Methods of the Croatian Sociological Association (HSD) in February 2011. I thank the participants at these two events for their helpful comments. I would also like to thank Professor William Corsaro, who first impressed upon me the importance of research rigour and ethical concerns in qualitative research.
} 
decisions and procedures. The researcher needs more safeguards for documenting her/his own involvement, both in interaction with the respondents and in the observing and interpreting their meanings. Further, the participantbased qualitative research is usually more immersive and labour-intensive in the data-gathering stage. In addition, the qualitative data-gathering can rarely be separated from the data-analysis. Therefore, by documenting the process of reaching and implementing the researcher's analytical and interpretative decisions, the qualitative researcher adds strength and credibility to the conclusions and makes the research more accessible for consideration of other interested researchers. ${ }^{1}$ However, while these procedures may indeed be very rigorous and self-reflexive in the qualitative research published in the Croatian social science journals, the problem the present paper highlights is that these procedures are typically not reported in these articles. Admittedly, such omissions can often be attributed to the journals' word limits, which force authors to strip their text of all but absolutely necessary information (elaborated later). Nevertheless, the absence of this information makes any in-depth evaluation of the quality and credibility of the reported results and their interpretation very difficult and further contributes to the often undeserved dismissal of the qualitative studies.

The main focus of the present paper is on the conventions of reporting on the participant-based qualitative research in the Croatian social science journals in the area of ethics and research rigour, which is complemented by a short discussion of institutional ethics procedures in the Croatian context. Discussing current practices necessarily means evaluating the existing conventions against a certain set of expectations about reporting on qualitative research. These standards are not necessarily agreed upon by all qualitative researchers. On the contrary, the issue of qualitative standards is hotly debated among various qualitative practitioners. Denzin (2009a) thus differentiates three possible positions: "foundationalists" seek a shared set of criteria in both qualitative and quantitative research, "quasi-foundationalists" argue for a particular set of standards adapted to the qualitative research, and "non-foundationalists" celebrate understanding and moral evaluation instead of criteria-setting. The former is Denzin's own position. He (2009a) vehemently argues against a single gold standard in evaluating qualitative research. In addition to the qualitative research being

\footnotetext{
${ }^{1}$ This certainly does not mean that the quantitative researchers should not be held similarly accountable. Indeed, some have asked quantitative researchers to document their data-analysis process more clearly (see, for example, Long, 2009). Nevertheless, the double standard still exists in the pressure weighing more heavily on the qualitative researchers to justify their research process and report biases.
} 
too diverse for uniform evaluation, he considers criteria-setting a political decision, one often directed against emancipatory and critical position of feminist and communitarian research. Similarly, Smith and Hodkinson (Hammersley, 2009; Smith and Hodkinson, 2009) argue for ever-changing and adapting qualitative criteria and for the evaluation of knowledge only within its socio-cultural and political context, which means it needs to be evaluated on moral and political grounds. In contrast, Hammersley (2009), while not opposing the need for open-ended criteria, argues that recognizing the social embededness of all knowledge does not equate with the impossibility to asses any knowledge claims and, therefore, he considers Smith and Hodkinson's rejection of epistemic criteria ungrounded.

The latter position is also the position of the present paper. It is based on the assumption that developing certain standards of qualitative research, which are adapted to its particular nature of examining the social world, increases the rigour and the credibility of such research. This is also a position congruent with the pragmatist research paradigm, which privileges problembased choice of method for examining the social world. ${ }^{2}$ In Flyvbjerg's words: "good social science is problem-driven and not methodologically-driven, in the sense that is employs those methods that for a given problematic best help answer the research questions at hand" (2004: 432). This, again, positions the perspective of this paper against the view of authors such as Denzin or Guba, who believe that the researcher's theoretical perspective positions her/him methodologically as well, and that the use of qualitative method presupposes certain theoretical position (Creswell, 2002). In the pragmatist, problem-based perspective, the methods are chosen according to their appropriateness for a particular question at hand. Therefore, the choice and the use of particular methods and the consequences of such decisions should be explicit. Following this line of argument, the present paper argues that the transparency in reporting on qualitative research is part of its rigorous procedure.

However, not all agree that such practice is desirable. Denzin (2009a), for example, believes that the demand for transparency of qualitative researchers reflects a lack of trust directed against them that is not directed against quantitative researchers. In contrast, Seale argues for the necessity of methodical awareness: "If there is one thing that produces poor studies, it is a researcher who is blind to the methodological consequences of researcher decisions" (Seale, 2002: 108). The present paper follows the latter position. The transparency of research decisions and their consequences is crucial for the credibility of any study - both in qualitative and quantitative research.

\footnotetext{
${ }^{2}$ For a more in-depth review of various research paradigms (post-positivism, constructivism, advocacy/participatory, pragmatism), see Creswell, 2002.
} 
Finally, a few caveats about the purpose of this paper are in order. First, I do not presume to interfere with other researchers' epistemological choices and the research decisions that follow from such choices. I acknowledge that some of the standards I use may be debatable among researchers following some other epistemological position or working in some other qualitative tradition. Nevertheless, the requirements of transparency and research rigour in reporting one's research decisions and strategies are not incompatible with any epistemological position. This is not to be interpreted as a demand for the justification of qualitative methods. Their legitimacy and significant contribution to the social sciences is well established. Indeed, many of the classical sociological contributions are ethnographies (e.g. the Chicago School work or, more recently, Bourdieu's work). Therefore, the main argument of the present paper is the plea for transparency in reporting on the qualitative research in social sciences. Whatever various epistemological choices and research decisions are, they should be explicit. The more transparent and rigorous standards of reporting serve to separate those qualitative studies that use their method as an excuse for poor science or undefined research questions from those of high quality, whose contribution to a better understanding of the social world should not be underestimated.

\section{Method and the description of the sample}

I examined articles using participant-based qualitative methods published in 2000-2009 in nine Croatian journals indexed in 2010 in the International Bibliography of Social Sciences (IBSS) and/or Social Sciences Citation Index (SSCI). The examined journals' primary disciplinary affiliations were sociology, social work, political sciences and psychology as the main social science disciplines whose research involves deeper interaction with "human subjects". The possible inclusion of ethnology/anthropology journals presented a dilemma. The use of qualitative methods is the mainstay of these two disciplines. However, this paper focused on the use of qualitative methods in social sciences. Ethnology and anthropology are variously classified as both humanities and social sciences, but the Croatian Ordinance on scientific and artistic areas, fields and branches (NVZ, 2009) classifies them as humanities. Further, the examination of 35 research articles using qualitative methods (mostly interviews) in three ethnological journals in 2000-2009, Etnološka tribina, Studia ethnologica Croatica and Narodna umjetnost, shows distinctly different reporting conventions from those of social science journals. ${ }^{3}$ For this reason, they are excluded from the analysis.

\footnotetext{
${ }^{3}$ Their topics usually examine customs, beliefs or identities of particular small communities and they treat their informants as experts, rather than respondents. As a result, the
} 
Next, I chose the IBSS and SSCI as inclusion criteria as they are reputable social science indices. This allowed for a manageable selection of quality publications to represent the current trends in the Croatian academic journal publishing. The complete list of journals, presented in Table 1, includes seven out of nine selected social science journals, as Suvremena psihologija and Socijalna ekologija in the examined period did not publish any articles satisfying my criteria for the inclusion in this study. To be included, the article had to use in-depth interviews, focus/group interviews, or participant observation as one of their main methods. Further, the article had to satisfy at least one of the following requirements: it had to be published by a Croatian author, in the Croatian language, or to examine some aspect of Croatian society. Table 2 presents the distribution of articles across disciplines. The main criterion for the definition of discipline was the author's own positioning in literature or discipline, followed, if necessary, by the author's institutional affiliation.

In the 2000-2009 period, the Croatian (predominantly) social science journals published the 43 participant-based qualitative articles examined in the present study. More than half of these articles were sociological, while others were mostly published from the perspectives of social work, pedagogy and related disciplines (Table 2). Most of the examined articles were published in Migracijske $i$ etnicke teme, followed by Ljetopis socijalnog rada and Društvena istraživanja. Most of the topics are related to the issues of identity, followed by children's experiences, quality of life, gender and migrations (Table 3).

Table 1. Number of qualitative articles in 7 Croatian social science journals, 2000-2009

\begin{tabular}{|l|r|}
\hline Journal & $N$ \\
\hline Migracijske i etničke teme & 12 \\
\hline Ljetopis socijalnog rada & 9 \\
\hline Društvena istraživanja & 8 \\
\hline Revija za sociologiju & 6 \\
\hline Sociologija i prostor (Sociologija sela) & 6 \\
\hline Revija za socijalnu politiku & 1 \\
\hline Politička misao & 1 \\
\hline Total & 43 \\
\hline
\end{tabular}

great majority of ethnology articles do not report on their method at all, but they immediately present information that was provided by their informants, who are usually identified by their full names and biographical information. 
Table 2. Distribution of qualitative articles across disciplines in Croatian social science journals, 2000-2009

\begin{tabular}{|l|c|}
\hline Discipline & $N$ \\
\hline Sociology & 26 \\
\hline Social Work & 7 \\
\hline Pedagogy & 3 \\
\hline Geography & 2 \\
\hline Ethnology & 1 \\
\hline Political Science & 1 \\
\hline Psychology & 1 \\
\hline Psychiatry & 1 \\
\hline Sociolinguistics & 1 \\
\hline Total & 43 \\
\hline
\end{tabular}

Table 3. Topics of qualitative articles in Croatian social science journals, 2000-2009

\begin{tabular}{|l|c|}
\hline Topic & $N$ \\
\hline Identity & 8 \\
\hline Children with special needs / in care & 6 \\
\hline Quality of life & 6 \\
\hline Gender & 4 \\
\hline Migrations & 4 \\
\hline Personal experiences & 3 \\
\hline Children in divorce & 2 \\
\hline Social/cultural integration & 2 \\
\hline Religious movement/group & 1 \\
\hline Tourism/public manifestations & 1 \\
\hline Free time / leisure & 1 \\
\hline Corruption perception & 1 \\
\hline Habitus & 1 \\
\hline Homeland War veterans & 1 \\
\hline Social reconstruction of community & 1 \\
\hline Urbanization & 1 \\
\hline Total & 43 \\
\hline
\end{tabular}

\section{The issue of research rigour}

The present paper argues that the qualitative articles should include the discussions of research rigour and ethics in order to enable readers to eval- 
uate satisfactorily the study's procedures, results and interpretations. The evaluations of research rigour, in my opinion, would benefit from two sets of information. At minimum, the information on research rigour should include a description of a method and a sample. This is usually unproblematic, as the basic description of a method and a sample is a part of the existing convention on reporting research, both qualitative and quantitative. However, the reports on research rigour would also benefit greatly from the discussions of more complex, but very important issues of generalizability, validity and reliability. ${ }^{4}$

\subsection{Generalizability}

Generalizability refers to the generalization of results beyond the examined group or sample. However, the generalizability in qualitative research is not probability-based, as it is in quantitative research. This absence of the probability-based generalizability is the reason why most researchers claim that the results, interpretations, and contributions of any such research are necessarily limited, since the qualitative researches cannot say much beyond the description of the group they are studying. Probability-based generalizability is indeed one of the greatest weaknesses of qualitative research and acknowledging the limitation of such research and its conclusions is necessary for any discussion of the generalizability of qualitative research. Nevertheless, the conclusions and the contributions of qualitative research cannot be so easily dismissed as purely descriptive or explorative. Instead, the majority of the qualitative researchers operate with a different conceptualization of generalizability, which is not probability, but theoreticallybased (for review of different uses of the concept of generalizability among qualitative researchers, see Gobo, 2008a). ${ }^{5}$

The main arguments for theoretically-based generalizability emphasize the contributions to the sociological knowledge that are made through

\footnotetext{
${ }^{4}$ I use the terms "generalizability", "validity" and "reliability" as the established terms for describing the issues they denote. However, I refer to their meanings as adapted to qualitative research, as opposed to the literal transplantation of these terms from the quantitative research. In addition, I use these terms, and not the alternative terms suggested in their stead for simplicity's sake. This does not imply a particular epistemological position on these issues.

${ }^{5}$ Admittedly, some qualitative researchers like Denzin reject generalizability as a positivist concern (Gobo, 2008a) and, instead, like Lincoln and Guba, they argue for alternative concepts (e.g. transferability), which assume the impossibility of the context-free interpretation (and thus of the generalization) of the qualitative data, although they may allow for some correspondence/transferability of the interpretations between some specific different sets of circumstances (Hammersley, 1992).
} 
the use and understanding of carefully and purposively selected cases or samples (Glaser and Strauss, 1967; Flyvbjerg, 2004; Hammersley and Atkinson, 2007; Gobo, 2008a). Flyvbjerg (2004) thus argues for the strategic choice of the case rich in information which enables some level of generalization, and may even allow for the falsification in Popper's sense of disproving the theory by providing a negative case. The cases chosen for their strategic value (extreme cases, critical or most likely/least likely cases, paradigmatic or exemplar cases or maximum variation cases) can provide more key information needed for the full understanding of the phenomenon than the (random sampling) representative cases necessarily do (Flyvbjerg, 2004).

These strategic choices of cases are in line with Shadish's earlier elaboration of how the core five principles of generalization, derived from experiments, can be applied to ethnographies. Specifically, Shadish (1995) claims that the principle of proximal similarity allows for the generalization in ethnographies based on the similarity of patterns across various contexts (cf. paradigmatic or typical cases). Next, the principle of heterogeneity of irrelevancies allows for the generalization based on the consistency of pattern across variations (cf. maximum variation cases). Further, the principle of discriminant validity allows for the generalization based on the presence or absence of a particular pattern crucially defining some phenomenon (cf. critical cases). Then, the principle of empirical interpolation and extrapolation allows for the generalization based on the limited variability in a strictly defined range of situations or outcomes (cf. maximum variation cases or even extreme cases). Finally, the principle of explanation allows for the generalization based on breaking down the phenomenon into its constituent parts in order to identify its essential characteristics (cf. paradigmatic or typical cases).

Going even further, Gobo (2008a) highlights various problems of the probability-based sampling and statistical inference and argues for an idiographic sampling theory in which representativeness is not taken to be a purely probability-based concept. Rather, the representativeness is based on the concept of variance, and such representative non-probability samples use three criteria in their construction: deductive inference (based on critical or extreme cases, often best suited for falsification in Popper's sense), comparative inference (based on extreme cases and maximum variation cases, which highlight certain features of the phenomenon) and theoretical inference (based on typical or emblematic cases, where the focus is on social similarities) (Gobo, 2008a). 


\subsubsection{Reporting on generalizability}

Generalizability in qualitative research is an issue that goes beyond saying that one's qualitative research is limited in its implications because it is not based on the probability-based sampling. This, indeed, is a limitation of the qualitative studies, and it should be acknowledged. However, such a statement alone is not sufficient for a satisfactory evaluation of a particular study. Qualitative researchers' decisions in designing their cases and their samples should be reported in their work, so that the readers can evaluate the implications and theoretical contributions of such a study. Even if the qualitative researchers follow authors like Denzin and reject the possibility of generalizability in qualitative research, then this also should be argued explicitly as an evaluative framework for a particular study. However, such more complex discussions of generalizability are currently not included in the qualitative articles published in the Croatian social science journals. Moreover, the majority of articles do not mention the issue of generalizability at all (Table 4). The minority that includes a discussion of generalizability limits this discussion to acknowledging a non-representative (non-probability-based) sample and possibly to limiting the implications of their conclusions as non-representative or just exploratory. Not one article discusses the strategic or theoretical considerations in the choice of the case or the construction of the sample, nor the wider theoretical implication of their results that follow from their strategic choices.

Table 4. Reporting on generalizability in qualitative articles in Croatian social science journals, 2000-2009 ( $N=43)$

\begin{tabular}{|r|c|c|c|}
\hline \multirow{2}{*}{$\begin{array}{l}\text { Reporting } \\
\text { Generalizability }\end{array}$} & \multicolumn{2}{|c|}{ Yes } & \multirow{2}{*}{ No } \\
\hline & \multicolumn{2}{|c|}{13} \\
\cline { 2 - 3 } & $\begin{array}{c}\text { Limitations of Non- } \\
\text { Probability Sample }\end{array}$ & $\begin{array}{c}\text { Generalizability of Case / } \\
\text { Sample }\end{array}$ & \\
\hline Yes & 13 & 0 & \\
\hline No & 0 & 13 & \\
\hline
\end{tabular}

\subsection{Validity}

Validity refers to the accurate representations of a studied phenomenon or its features (Hammersley, 1992; Becker, 1996). As one of the central qualitative issues, validity garners heated discussion. In qualitative adaptation, it usually includes assessing if the study examines what it purports to or providing checks for the evaluation of the evidence on which the interpretations are based (for review of different uses of the concept of validity among qualita- 
tive researchers, see Whittemore, Chase and Mandle, 2001). Such concerns range from the issues of the appropriateness of the chosen method or the sample for the research questions to the issues of the appropriate interpretations of the results. However, many authors prefer some other concepts to validity, which often move the discussion from the area of data-gathering or analysis to interpretation. Thus, for example, the concepts of "credibility" and "authenticity" focus on the accuracy of interpretations in terms of them fitting the participant's meanings and experiences or being plausible within the research context (Whittemore, Chase and Mandle, 2001).

Qualitative researchers designed several techniques for checking the validity of their data. ${ }^{6}$ Some of the perhaps most prominent are the triangulation, member validation and negative cases. Lindlof and Taylor (2002) define triangulation as the comparison of two or more forms of evidence, where the goal is to arrive at similar meanings from various directions. This can include multiple data sources, multiple methods, multiple researchers/analysts or multiple theories/perspectives (Denzin, 2009b; Lindlof and Taylor, 2002; Hammersley and Atkinson, 2007). The triangulation will necessarily include inconsistencies in interpretations across various sources or methods or analysts or theoretical perspectives. Some consider this an argument against triangulation, and argue for the incommensurability of triangulation approaches taken out of their contexts (Silverman, 2006). Others do not consider such inconsistencies problematic as long they are in line with the different ways of gathering or interpreting the data and if the researcher understands and can explain them (Patton, 1990). Fielding (2009), for example, believes that triangulation helps making the researcher's assumptions explicit, and while it does not guarantee validity, it provides better understanding.

Member or respondent validation refers to checking the researcher's interpretations against the respondents' interpretations (Rizzo, Corsaro and Bates, 1992; Lindlof and Taylor, 2002; Hammersley and Atkinson, 2007). This does not necessarily mean that the respondents' interpretations will be privileged over the researcher's interpretations. Rather, the member validation is usually considered a type of (analyst) triangulation, where the respondents provide another perspective of the data (Hammersley and Atkinson, 2007).

\footnotetext{
${ }^{6}$ Cho and Trent (2006) classify attempts to achieve qualitative validity by particular techniques of "transactional validity". This position is opposed by "transformational validity", which rejects the idea that validity can be achieved by particular techniques. Instead, one should look at the reflexivity and morality of the results to evaluate a study's validity. However, even the supporters of transactional validity do not claim the use of validity checks guarantees validity (Hammersley, 2009). Rather, they see them as necessary, but not sufficient for a study's validity (Cho and Trent, 2006).
} 
Finally, looking for negative cases refers to going back into the data and searching for the instances that disrupt the patterns the researcher has found, or that are not congruent with the researcher's interpretations (Rizzo, Corsaro and Bates, 1992; Becker, 1998; Patton, 1990). In addition, some authors also argue for the relevance of the researcher's credibility in interpreting the results, so they suggest that the qualitative study reports should include information on the researcher's position, biases and personal or professional details that might have influenced the research situation or the data interpretation (Patton, 1990; Hammersley and Atkinson, 2007).

\subsubsection{Reporting on validity}

Reporting on validity would include three levels of reporting within the perspective of transactional validity. First is the argument for the appropriateness of the chosen method and sample for answering the researcher's specific questions. This discussion should move beyond the obsolete discussion of whether the qualitative methods are a legitimate tool for understanding the social world. Rather, this discussion should focus on whether the particular qualitative method used is appropriate for answering the posed research questions (for example, why focus on group interviews instead of individual in-depth interviews). Second, providing methodological details about the research process (e.g. interview guides) would further help the discerning reader to evaluate if what is measured is what is claimed to be measured. For example, qualitative researchers examining constructions of identities typically do not ask their respondents about their identity. Rather, they construct these meanings from specific questions. The insight into this process should be made available to the readers. Further, if the qualitative researchers used validity checks (such as triangulation, negative cases or some other techniques), they should report on them. Finally, they should disclose their position, which may have influenced the data-gathering, analysis or the interpretations.

Only ten out of 43 Croatian qualitative articles in social science journals in 2000-2009 discussed the issue of validity (Table 5), where, to be classified as such, the article had to discuss at least some concrete issue and not just generally mention validity. Other conceptualizations of validity were not mentioned at all. Six articles discussed validity of method, that is, the appropriateness of their method for answering their research question(s). None discussed the appropriateness of their sample. Further, four articles gave concrete examples from their work, which provided a limited insight into the accuracy of their measures (mainly, the excerpts 
from the interview schedules). Finally, one article mentioned the issue of triangulation, and one article mentioned they used member validation for checking the validity of their data.

Table 5. Reporting on validity in qualitative articles in Croatian social science journals, 2000-2009 ( $N=43)$

\begin{tabular}{|r|c|c|c|c|c|}
\hline \multirow{2}{*}{$\begin{array}{l}\text { Reporting } \\
\text { Validity }\end{array}$} & \multicolumn{4}{|c|}{ Yes } & \multirow{2}{*}{ No } \\
\hline & \multicolumn{4}{|c|}{10} \\
\cline { 2 - 5 } & $\begin{array}{c}\text { Validity of } \\
\text { Method }\end{array}$ & $\begin{array}{c}\text { Validity of } \\
\text { Sample }\end{array}$ & $\begin{array}{c}\text { Validity: } \\
\text { Examples }\end{array}$ & $\begin{array}{c}\text { Validity } \\
\text { Checks }\end{array}$ & \\
\hline Yes & 6 & 0 & 4 & 2 & \\
\hline No & 4 & 10 & 6 & 8 & \\
\hline
\end{tabular}

\subsection{Reliability}

Reliability is related to the degree of consistency in the observation or categorization of the examined patterns (Hammersley, 1992; Lindlof and Taylor, 2002). This typically refers to consistency of the measuring instrument or replicability of results (Silverman, 2006; Gobo, 2008b). It is, therefore, less relevant in qualitative studies where the researcher is the instrument and the studies are usually based on non-repeatable events (such as observation or interviews) (Lindlof and Taylor, 2002). Nevertheless, the qualitative re-conceptualizations of reliability are often intertwined with the issue of validity and credibility (Rizzo, Corsaro and Bates, 1992; Gobo, 2008b). Hence, some researchers believe that the reliability of qualitative studies is enhanced by rigorous procedure that is made transparent to the readers and the academic community (Silverman, 2006; Gobo, 2008b). For example, Gobo (2008b) re-conceptualizes reliability as internal and external accuracy, where internal accuracy refers to the researcher's rigour, and external accuracy to the accountability in providing documentation necessary to assess the research. Similarly, Lincoln and Guba (Seale, 2002) talk about the dependability of qualitative research, instead of reliability, which is achieved by auditing or documenting every stage of the research process. Furthermore, we can also talk about reliability in some stages of the qualitative data-analysis. This might, for example, include the creation of coding categories in qualitative analysis, as some authors argue that the stability of the coding categories should be checked by other coder/s (inter-coder reliability). However, not all agree that this is useful or practical, or even desirable (Rizzo, Corsaro and Bates, 1992; Lindlof and Taylor, 2002). Nevertheless, the process of creating theoretical constructs out of the raw data 
should be transparent, as this strengthens the confidence in the researcher's final interpretations.

\subsubsection{Reporting on reliability}

Reporting on reliability, then, would provide means for a discerning reader to evaluate the qualitative research process. This being the main topic of this paper, I refer readers to the conclusions, while in this section I will discuss only the information the researchers provided on the techniques they used, if any, to ensure the reliability of their data-analysis, and on the concrete examples of the process of getting from raw data to the theoretical categories and interpretations.

Only eight out of 43 qualitative articles in the Croatian social science journals in 2000-2009 reported on the issues of reliability (Table 6), where to be categorized as such, the articles had to provide concrete arguments and examples, and not just mention theory on, for example, the coding process in general. The majority of the articles provided an excerpt from the coding process (from line-by-line code to categories), while two articles also mentioned the use of inter-coder checking of the reliability of the coding categories.

Table 6. Reporting on reliability in qualitative articles in Croatian social science journals, 2000-2009 ( $N=43)$

\begin{tabular}{|r|c|c|c|}
\hline \multirow{2}{*}{$\begin{array}{c}\text { Reporting } \\
\text { Reliability }\end{array}$} & \multicolumn{2}{|c|}{ Yes } & \multirow{2}{*}{ No } \\
\hline \multirow{2}{*}{} & \multicolumn{2}{|c|}{35} \\
\cline { 2 - 3 } & $\begin{array}{c}\text { Reliability of Data- } \\
\text { Analysis: Examples }\end{array}$ & $\begin{array}{c}\text { Reliability of Data- } \\
\text { Analysis: Inter-Coder }\end{array}$ & \\
\hline Yes & 7 & 2 & \\
\hline No & 1 & 6 & \\
\hline
\end{tabular}

\section{The Issue of ethics}

As a rule, every university or research institution has an ethical codex professing the protection of "human subjects". The University of Zagreb ethical codex, for example, talks about protecting the rights and dignity of the participants in research. However, implementing the practices that regulate and sanction ethical (mis)conduct, particularly before the fact (e.g. some gross misconduct) are rarely as up to par. This is of particular relevance in the participant-based qualitative research where the issues of power and influence emerge in much more visible ways. The present paper argues that Croatian qualitative research is characterized by a weak institutional 
accountability in the area of ethics regulations, and that this weak institutional accountability further reinforces the undeveloped conventions of reporting on ethical issues in the qualitative research published in Croatian social science journals.

The ethical concerns in the participant-based qualitative research refer to a wide array of issues. At the most basic level, the ethics procedure revolves around the entry into the field, where the "field" is any situation of involved interaction with the research participants. This, for example, may include the introduction into the field, the gatekeepers, the relations to the institutions the researchers represent, gaining trust, the implicit pressures, and so on. Next is the issue of anonymity, or, more often, confidentiality (as anonymity is rarely truly possible in qualitative research). This is particularly troublesome in the studies of small or easily identifiable communities. The issue of consent is also important, and particularly the differences between the informed and the implied consent (Berg, 1998). The written informed consent, where the respondents guarantee their willing and knowledgeable participation with a signature may be ethically "safer" than the implied consent, where the participants agree informally before the research. However, the written informed consent preserves the paper trail that weakens the confidentiality, and also, its formality and its implications may have an adverse effect on the research situation (Berg, 1998).

Some other issues are not always considered. There is, for example, preserving and securing the data (Berg, 1998). Where will the data be kept? How will the researcher ensure that it does not become available to anybody but the researcher? Will anybody else have access to the data (e.g. transcribers), and if so, how is their confidentially ensured (e.g. confidentiality contracts with the transcribers)? How long will the researcher keep the data with the potentially identifying information (e.g. tapes of interviews)?

Next, another issue is the reciprocity (Patton, 1990). Will the respondents be compensated for their participation? Should they be, and how is this decision affected by the respondent status (say, if they are a disadvantaged or marginalized group) $?^{7}$ If they are compensated, how may this affect the research situation? There are also alternative definitions of reciprocity, where the respondents are not compensated by cash or similar awards, but there is reciprocation, for example, in showing them the significance of their contribution or showing them that their stories are valued (Patton, 1990).

\footnotetext{
${ }_{7}$ This issue is somewhat controversial. Some researchers are reluctant to offer compensation to their research participants for various ethical reasons or in fear of furthering an incentives-dominated society, while others believe that the payment for research participants' effort and time is their due (Patton, 1990).
} 
The final issue is the issue of sanctions. If any ethical misdemeanour does occur, were the respondents clearly informed beforehand on their options for reporting such behaviour? Furthermore, in anticipation of the issue of institutional accountability, who will sanction misconduct and how?

\subsection{Reporting on ethics}

Not all issues described above will find their publication space. Considering the restraints on article length and many other relevant issues to be discussed, this is not necessarily problematic. Some information indicating that the researcher followed the basic ethical procedures or the disclosure of the information relevant for the data-gathering and the interpretation should be present (e.g. field entry and the issues of confidentiality and the respondent's consent). Other issues, however, may be reasonably absent from the article. Nevertheless, what should serve in their stead is the information that this particular study has passed the institutional ethical review process. This way, although all other important ethical issues are not reported, the reader could be confident that they were indeed considered. Therefore, the qualitative researchers are expected to provide information on how they entered the field and received the respondents' consent, to preserve the confidentiality of their respondents in the publication, and to indicate whether the study has been institutionally approved by an ethical committee.

In the Croatian social science journals in 2000-2009, about half of the qualitative publications reported on at least one basic ethical issue, although what was reported varied across articles (Table 7). Ten articles reported how the researcher/s entered the field and twelve articles reported they gained the respondents' consent for participation in the study. Twelve articles also reported that their respondents were guaranteed confidentiality. None reported on gaining institutional approval for their study.

Table 7. Reporting on ethical concerns in qualitative articles in Croatian social science journals, 2000-2009 ( $N=43)$

\begin{tabular}{|c|c|c|c|c|c|}
\hline \multirow{3}{*}{$\begin{array}{l}\text { Reporting } \\
\text { Ethics }\end{array}$} & \multicolumn{4}{|c|}{ Yes } & No \\
\hline & \multicolumn{4}{|c|}{23} & \multirow[t]{4}{*}{20} \\
\hline & Entry & Consent & Confidentiality & $\begin{array}{c}\text { Institutional } \\
\text { Approval }\end{array}$ & \\
\hline Yes & 10 & 12 & 12 & 0 & \\
\hline No & 13 & 11 & 11 & 23 & \\
\hline
\end{tabular}




\subsection{Institutional accountability}

In the previous section, I argued that the report on institutional ethical approval can serve instead of reporting on all the gritty ethical details in the qualitative publications. The underlying assumption of this argument is that the institutional ethical review is indeed a rigorous process that addresses all the necessary ethical concerns. Unfortunately, this is not always and completely true in the Croatian social sciences. Part of the problem is the absence of institutional standards or any shared institutional accountability. In the majority of cases, the institutional ethical review depends solely on a particular department or institution. ${ }^{8}$ As a result, the ethical requirements vary widely across institutions, and even across the departments within the same institution.

Table 8. Formal ethical procedure requirements for undergraduate research in selected Croatian social science departments

\begin{tabular}{|c|c|c|c|c|c|c|c|c|}
\hline \multicolumn{3}{|c|}{$\begin{array}{l}\text { Ethical Procedures Form for } \\
\text { Undergraduate Research }\end{array}$} & \multirow{2}{*}{$\begin{array}{c}\text { Confidentiality } \\
\text { yes }\end{array}$} & \multirow{2}{*}{$\begin{array}{c}\text { Consent } \\
\text { yes }\end{array}$} & \multirow{2}{*}{\begin{tabular}{|c|} 
Research \\
Information \\
yes
\end{tabular}} & \multirow{2}{*}{\begin{tabular}{|c|} 
Data \\
Storage
\end{tabular}} & \multirow{2}{*}{$\begin{array}{c}\text { Benefits } \\
\text { / Harms } \\
\text { yes }\end{array}$} & \multirow{2}{*}{$\begin{array}{c}\text { Feedback } \\
\text { no }\end{array}$} \\
\hline \multirow{5}{*}{ 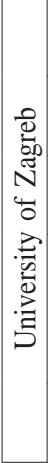 } & $\begin{array}{l}\text { Sociology } \\
\text { FF }\end{array}$ & Yes & & & & & & \\
\hline & $\begin{array}{l}\text { Psychology } \\
\text { FF }\end{array}$ & Yes & yes & yes & yes & yes & yes & yes \\
\hline & $\begin{array}{l}\text { Sociology } \\
\text { HS }\end{array}$ & No & - & - & - & - & - & - \\
\hline & $\begin{array}{c}\text { Psychology } \\
\text { HS }\end{array}$ & $\begin{array}{l}\text { Only if } \\
\text { children or } \\
\text { deception } \\
\text { involved. }\end{array}$ & $n / a$ & n/a & $n / a$ & n/a & n/a & n/a \\
\hline & $\begin{array}{l}\text { Social } \\
\text { Work }\end{array}$ & Yes & yes & yes & yes & no & yes & yes \\
\hline \multirow{2}{*}{ 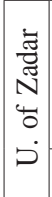 } & Sociology & \begin{tabular}{|c} 
Informed \\
Consent \\
Form for \\
Respondents.
\end{tabular} & - & - & $\begin{array}{c}\text { Study } \\
\text { Information } \\
\text { Form }\end{array}$ & - & - & - \\
\hline & Psychology & $n / a$ & $\mathrm{n} / \mathrm{a}$ & n/a & $\mathrm{n} / \mathrm{a}$ & $\mathrm{n} / \mathrm{a}$ & $\mathrm{n} / \mathrm{a}$ & $\mathrm{n} / \mathrm{a}$ \\
\hline \multicolumn{2}{|c|}{$\begin{array}{l}\text { U. of Rijeka } \\
\text { Psychology }\end{array}$} & No & - & - & - & - & - & - \\
\hline \multicolumn{2}{|c|}{$\begin{array}{l}\text { U. of Split } \\
\text { Sociology }\end{array}$} & No & - & - & - & - & - & - \\
\hline \multicolumn{2}{|c|}{$\begin{array}{l}\text { U. of Osijek } \\
\text { Psychology }\end{array}$} & Yes & no & yes & yes & no & yes & no \\
\hline
\end{tabular}

FF $=$ Faculty of Humanities and Social Sciences; HS = University Centre for Croatian Studies n/a: Information not available

${ }^{8}$ I consider here only the research with consenting adults, and not children, to whom special rules apply. 
As an illustration, I examined the formal ethnical requirements at the Croatian sociology, social work and psychology departments at the level of undergraduate research (Table 8). This information, therefore, does not consider possible oral or informal instructions the students may or may not receive, but only the ethical issues they must address in written form before getting approval for their research. The psychology departments typically have the most developed formal ethical procedures. For example, the psychology students at the Faculty of Humanities and Social Sciences in Zagreb are required formally to address most of the issues mentioned at the beginning of this section: anonymity/confidentiality, consent, information provided to their respondents, storage of data, the benefits and harms and the feedback given to the respondents on the study results. In contrast, among the sociology departments, the requirements are typically less formalized, with the exception of the sociology department at the Faculty of Humanities and Social Sciences in Zagreb, whose ethics application for undergraduate students addresses most of the above-mentioned issues except the issue of feedback.

The undergraduate research is the first instance of acquiring ethical sensibility, as well as the research level where the formal ethical regulations are most easily implemented. Nevertheless, unified standards and a shared institutional accountability are absent at this level. What, then, happens at the higher levels of research, considering that there is no university-level institutional review process and that many researchers have multiple institutional or funding affiliations? For example, to which review process does the faculty at individual departments apply if their research is funded by an outside source with their own ethical procedures? What if their particular institution has no formal or has only a rudimentary ethical review process? If some particular research involves students from a different institution, should this institution require the researchers to pass their review? These are only some of many issues that could be raised, and they all share the same underlying question. Where is the locus of the institutional accountability? The absence of unified standards and great variety of ethical requirements make it very easy for these issues simply to become lost among various rules of various institutions at various levels or to become entangled with the political questions of autonomy of various institutions.

\section{Problems and limitations}

One of the concerns raised in relation to the ethical committees and formal procedures is the over-regulation and bureaucratization that thwarts actual research. The concern about the over-codification and bureaucratization of 
research is not unfounded. Lincoln (2005), for example, criticizes US institutional review boards (IRBs) for not keeping pace with the developments in the research methodologies and for propagating methodological conservatism, which is particularly problematic for qualitative research. Another objection often directed at the IRBs is the same Becker (2009) makes against the Sociology Division of the US National Science Foundation. Due to their quantitative hypothesis-based research bias, they demand to know every single step of the research beforehand. This, in qualitative research, is hardly possible as the qualitative process is iterative and "one could never know what ideas would need to be investigated and tested until the research began" (Becker, 2009: 545). Similarly, Tiernay and Blumberg Corwin (2007) describe how the US IRBs can limit the researcher's academic freedoms in designing and conducting their research. However, the current absence of any standardized or unified ethical procedures in the Croatian social sciences is not a satisfactory alternative. Moreover, such a situation can lead to even more bureaucratic entanglements as each institution can demand that their rules be followed. Having university-wide or, even better, professional community-wide defined guidelines about the requirements of an ethical review process, which can then be standardized across various institutions, would go a long way in avoiding possible multiple review processes and in raising confidence that all the research considered and followed ethical procedures in accordance with the standards of their own profession.

I believe that the majority of researchers are sensitive to the ethical issues and that they are careful to implement their research in ethically satisfactory ways. However, they may chafe at the restraints and the bureaucratization that the formalized ethical applications may bring. Then again, such rules were established to prevent the minority that may be less sensitive, or to sensitize those researchers who just may not have enough experience to anticipate fully the consequences of some of their research decisions. Sociologists have evidence from their own academic history that such cases happen. One infamous example of an ethically troublesome case is Carolyn Ellis' research on the Guineamen community in Virginia, USA, where she visited this particular fishing community - which she later presented as illiterate, unhygienic and backward - for nine years without ever disclosing she was studying them, and caused a lot of hurt and strained relations when her research was published in 1986 (Allen, 1997). This is an extreme case, but the ethical considerations and dilemmas are rarely easy or obvious. Hence, I believe that the trade-off between a moderate increase in bureaucratic (standardized) rules and preventing harm to the respondents 
that may happen because some ethical issues may have not be considered in more in-depth ways speaks in favour of the more developed formalized ethical review process.

Related to the issue of reporting on ethics and research rigour in the journals, the most obvious problem is the limitation of space. Journal word limits are typically tailored to the quantitative pieces, which can more easily report on both their results and the methodological necessities in 7000 to 8000 words. For the qualitative pieces, with their lengthier descriptions of results and interpretations, it is sometimes almost impossible to incorporate both the necessary results and the information on the research rigour and ethics. However, if this information is absent, then the discernible readers are not able to judge the credibility of the presented results and interpretations, and the misconceptions about the "non-scientific" nature of qualitative research are further reinforced. Therefore, despite the objective space limitations (a problem shared by the non-Croatian journals), the absence of the details on the research rigour and ethics is a problem that cannot and must not be ignored.

In addition, there are ways around it. Ideally, the journals would adapt their length requirements to the different needs of the qualitative research. But, if that is not feasible, there are other solutions. For example, all the Croatian journals examined in this study publish their issues online. Therefore, the necessary information on the research rigour and ethics not included in the body of the article can be published in online-only methodological supplements. The precedent to such practice already exists. Looking only at February 2011 and April 2011 issues of the American Sociological Review, nine out of twelve published articles also have online supplements.

\section{Conclusion}

Seven Croatian (predominantly) social science journals indexed in 2010 in the International Bibliography of Social Sciences (IBSS) and/or Social Sciences Citation Index (SSCI) in 2000-2009 published only 43 qualitative publications. Such a relatively small number signals that the Croatian social sciences may still lag behind the qualitative turn occurring in other academic communities, at least if we judge the situation by the Croatian journal production. Undeveloped conventions of reporting on qualitative research further testify to this lag. Only a minority of articles reported on the issues of research rigour (generalizability, validity, reliability) and ethics, and even when such reports were present, they were in most cases rudimentary. 
In conclusion, what is to be done to make the reports on the qualitative research and ethical issues more transparent, so that such research can be evaluated on its own merits? The first responsibility, naturally, lies with the individual researchers who should consider and report on their research strategies and the decisions that shaped their study. Next, and perhaps even more importantly, there is a responsibility on the journals' editorial boards and the reviewers of the qualitative studies. The editors should be careful in choosing reviewers who are trained or experienced or sensitive to the particular issues of the qualitative research. The editors should also be judicious in assessing the comments of the reviewers demanding quantitative research standards from a qualitative study. The reviewers of the qualitative research, on the other hand, should evaluate the qualitative studies on their own merits and they should also insist that the qualitative studies report on the issues of research rigour and ethics to make such an evaluation possible. Finally, in the area of ethics, a certain level of institutional accountability is needed, as the institutional safeguards before the fact are even more important in this particular domain than the publishing pressures and the reporting conventions. Nevertheless, the publishing pressures and reporting conventions are indeed important as they shape the face of the research in an academic community and raise the consciousness about these issues. Therefore, what is needed in the Croatian social sciences is a shift from an individual researcher's "good will" to do qualitative research correctly to the functioning system of institutional and publishing standards. Without such a functioning system, in which the demands for the rigorous research procedures and ethical protocols are common-place, we can talk neither of mature qualitative research nor of the qualitative turn.

\section{REFERENCES}

Allen, Charlotte (1997). "Spies Like Us: When Sociologists Deceive Their Subjects", Lingua Franca, 7 (9): 31-39.

Becker, Howard S. (1996). "The Epistemology of Qualitative Research", in: Richard Jessor, Anne Colby and Richard A. Shweder (eds). Ethnography and Human Development: Context and Meaning in Social Inquiry. Chicago: University of Chicago Press, pp. 53-71.

Becker, Howard S. (1998). Tricks of the Trade: How to Think about Your Research While You're Doing It. Chicago: University of Chicago Press.

Becker, Howard S. (2009). "How to Find out How to Do Qualitative Research", International Journal of Communication, 3: 545-553.

Berg, Bruce L. (1998). Qualitative Research Methods for the Social Sciences. Boston: Allyn \& Bacon. 
Cho, Jeasik and Trent, Allen (2006). "Validity in Qualitative Research Revisited", Qualitative Research, 6 (3): 319-340. doi:10.1177/1468794106065006

Creswell, John W. (2002). Research Design: Quantitative, Qualitative, and Mixed Methods Approaches. 2nd ed. Thousand Oaks: Sage.

Denzin, Norman K. (2009a). "The Elephant in the Living Room: Or Extending the Conversation about the Politics of Evidence", Qualitative Research, 9 (2): 139-160. doi:10.1177/1468794108098034

Denzin, Norman K. (2009b). The Research Act: A Theoretical Introduction to Sociological Methods. Piscataway, NJ: Aldine Transaction.

Fielding, Nigel G. (2009). "Going out on a Limb: Postmodernism and Multiple Method Research”, Current Sociology, 57 (3): 427-447. doi:10.1177/0011392108101591

Flyvbjerg, Bent (2004). "Five Misunderstandings about Case-Study Research", in: Clive Seale, Giampietro Gobo, Jaber F. Gubrium and David Silverman (eds). Qualitative Research Practice. London: Sage, pp. 420-434.

Glaser, Barney G. and Strauss, Anselm L. (1967). The Discovery of Grounded Theory: Strategies for Qualitative Research. Chicago: Aldine.

Gobo, Giampietro (2008a). "Re-conceptualizing Generalization: Old Issues in a New Frame", in: Pertti Alasuutari, Leonard Bickman and Julia Brannen (eds). The Sage Handbook of Social Research Methods. London: Los Angeles, pp. 193-213.

Gobo, Giampietro (2008b). Doing Ethnography. Los Angeles: Sage.

Hammersley, Martyn (1992). What's Wrong with Ethnography? Methodological Explorations. London and New York: Routledge.

Hammersley, Martyn (2009). "Challenging Relativism: The Problem of Assessment Criteria”, Qualitative Inquiry, 15 (1): 3-29. doi:10.1177/1077800408325325

Hammersley, Martyn and Atkinson, Paul (2007). Ethnography: Principles in Practice. 3rd ed. London and New York: Routledge.

Lincoln, Yvonna S. (2005). "Institutional Review Boards and Methodological Conservatism: The Challenge to and from Phenomenological Paradigms", in: Norman K. Denzin and Yvonna S. Lincoln (eds). The Sage Handbook of Qualitative Research. 3rd ed. Thousand Oaks: Sage, pp. 165-181.

Lindlof, Thomas R. and Taylor, Bryan C. (2002). Qualitative Communication Research Methods. 2nd ed. Thousand Oaks: Sage.

Long, J. Scott (2009). The Workflow of Data Analysis Using Stata. College Station, Tex.: Stata Press.

NVZ (2009). Pravilnik o znanstvenim i umjetničkim područjima, poljima i granama, Narodne novine, 118/09.

Patton, Michael Quinn (1990). Qualitative Evaluation and Research Methods. Newbury Park, CA: Sage.

Rizzo, Thomas A., Corsaro, William A. and Bates, John E. (1992). "Ethnographic Methods and Interpretive Analysis: Expanding the Methodological Options of Psychologists", Developmental Review, 12 (2): 101-123. doi:10.1016/02732297(92)90005-M

Seale, Clive (2002). "Quality Issues in Qualitative Inquiry”, Qualitative Social Work, 1 (1): 97-110. doi:10.1177/147332500200100107 
Shadish, William R. (1995). "The Logic of Generalization: Five Principles Common to Experiments and Ethnographies", American Journal of Community Psychology, 23 (3): 419-428. doi:10.1007/BF02506951

Silverman, David (2006). Interpreting Qualitative Data: Methods for Analyzing Talk, Text and Interaction. 3rd ed. London: Sage.

Smith, John K. and Hodkinson, Phil (2009). "Challenging Neorealism: A Response to Hammersley”, Qualitative Inquiry, 15 (1): 30-39. doi:10.1177/1077800408325416

Tierney, William G. and Blumberg Corwin, Zoë (2007). "The Tensions between Academic Freedom and Institutional Review Boards", Qualitative Inquiry, 13 (3): 388-398. doi:10.1177/1077800406297655

Whittemore, Robin, Chase, Susan K. and Mandle, Carol Lynn (2001). "Validity in Qualitative Research", Qualitative Health Research, 11 (4): 522-537. doi:10.1177/104973201129119299

\title{
Izvještavanje o pitanjima istraživačke rigoroznosti i etike: slučaj radova koji se koriste kvalitativnim metodama u hrvatskim časopisima društvenih znanosti
}

\author{
Tanja VUČKOVIĆ JUROŠ \\ Studijski centar socijalnog rada, Pravni fakultet Sveučilišta u Zagrebu \\ tanja.vuckovic.juros@gmail.com
}

Ovaj rad raspravlja pitanja istraživačke rigoroznosti i etike u kvalitativnim istra-
živanjima na slučaju istraživanja objavljenih u hrvatskim časopisima društvenih
znanosti. Autorica raspravlja uporabu koncepata poopćivosti, valjanosti i pouz-
danosti u kvalitativnim istraživanjima i važnost etičkih pitanja te razmatra uzuse
izvještavanja o ovim pitanjima u hrvatskim časopisima društvenih znanosti. U
tu svrhu, autorica je pregledala članke koji rabe kvalitativne metode koje uklju-
čuju interakciju istraživača sa sudionicima istraživanja (dubinski intervjui, foku-
snoskupinski intervjui, promatranje) i koji su objavljeni u razdoblju 2000-2009.
u sedam hrvatskih časopisa indeksiranih u International Bibliography of Social
Sciences (IBSS) i/ili u Social Sciences Citation Index (SSCI). Rezultati svjedoče
o nedovoljno razvijenim uzusima izvještavanja o etičkim pitanjima koja su done-
kle i rezultat slabe institucionalne odgovornosti u području etičkih regulacija. K
tomu, pogrešna predodžba o nedostatku istraživačke rigoroznosti pri provođenju
kvalitativnih istraživanja često je razlogom optužbi o »nedovoljnoj znanstveno-
sti« tih istraživanja. No, upravo suprotno, dobra kvalitativna istraživanja vode
se još strožim pravilima istraživačke odgovornosti u vezi s pojedinim odluka-
ma i procedurama. Ipak, kako izvještaji o istraživačkim koracima i razmatranja
pitanja poopćivosti, valjanosti i pouzdanosti, prilagođenih prirodi kvalitativnog
istraživanja, u velikoj većini nedostaju u hrvatskim radovima koji se koriste kva- 
litativnim metodama, tako pogrešne predodžbe o kvalitativnim istraživanjima i dalje opstaju, a zahtjevan čitatelj ne može procijeniti kredibilnost i legitimnost istraživačkih rezultata.

Ključne riječi: istraživačka rigoroznost, etika, kvalitativna istraživanja, poopćivost, valjanost, pouzdanost, društvene znanosti 